\title{
Permanent Establishment in the Form of Dependent Agent in the Light of the Base Erosion and Profit Shifting Project
}

\author{
Agata Lipińska
}

Abstract: The subject of the paper is an analysis of the issue of permanent establishment in the form of a dependent agent. The main purpose is to list the positive conditions leading to the setting up of a permanent establishment in the form of a dependent agent. The paper examines the issue of indication of characteristics of the agent's dependence on the enterprise under the Organisation for Economic Co-operation and Development's Model Convention. The definition of a dependent agent contained in the Organisation for Economic Co-operation and Development's Model Convention is analysed in the context of the Polish company law regulations. The author made an attempt to characterize the institute, taking into account the differences between the versions of the Organisation for Economic Cooperation and Development's Model Convention of years 2014 and 2017, and to present the advantages and disadvantages of the concept of a dependent agent.

Key Words: Financial Law; Tax Law; International Tax Law; Taxation; Double Taxation; Avoidance of Double Taxation; Taxation of Economic Activities; Organisation for Economic Co-operation and Development; Organisation for Economic Co-operation and Development's Model Convention; Base Erosion and Profit Shifting Project; Dependent Agent; Permanent Establishment; Poland.

\section{Introduction}

The permanent establishment is one of the key institutions under the Organisation for Economic Co-operation and Development's Model Convention (hereinafter referred to as the "OECD Model Convention"). It constitutes a form of direct investment in foreign markets. ${ }^{1}$ It is intended to allow one-off taxation on the income of the enterprise the permanent establishment is part of. It is used wholly or partly to run the business of

1 See JAMROŻY, M. Planowanie podatkowe działalności prowadzonej poprzez zagraniczny zakład. Studia Ekonomiczne. 2014, nr 198, p. 255. ISSN 2083-8611. 
the enterprise in the territory of the source state. Therefore, the identification of an establishment has a direct impact on the possibility of determining the amount of the enterprise's income and the method of assigning profits between the state of residence and the source state. The establishment can be used as a part of tax planning. Under the OECD Model Convention, there are three main forms of the permanent establishment: general permanent establishment, construction permanent establishment and agency permanent establishment.

The basing of the construction of the establishment solely in its basic form, i.e. a general permanent establishment, in accordance with the provisions of the Article 5(1) of the OECD Model Convention, would enable enterprises to avoid tax by using the services of representatives or sellers in the source state. Therefore, the establishment of an enterprise which does not have a general permanent establishment in the source state, but is represented by a specific person defined in the OECD Model Convention may be established. It must, therefore, be assumed that the concept of a dependent agent constitutes an extension of the definition of the permanent establishment in its basic form and is applied only once the conditions set out in the Article 5(1) to (3) of the OECD Model Convention, namely the conditions for setting up an establishment in the form of a general permanent establishment and a construction permanent establishment, are excluded. ${ }^{2}$ At the same time, if those conditions are met, there is no need to prove that the person operating the permanent establishment is a dependent agent of the enterprise.

Article 5(5) of the 2014 version of the OECD Model Convention contained the definition of an establishment in the form of a dependent agent. According to its content, an establishment is set up in the territory of a contracting state if the person concerned acts on behalf of the enterprise and also has and habitually exercises the authority to conclude contracts on its behalf. This is about any activity that the person undertakes for the benefit of the enterprise. The exception will be the activities listed

2 See BANACH, J. Polskie umowy o unikaniu podwójnego opodatkowania: Komentarz. 2. wyd. Warszawa: C. H. Beck, 2002, p. 135. ISBN 83-7247-904-6; and PERSICO, G. Agency Permanent Establishment under Article 5 of the OECD Model Convention. Intertax. 2000, vol. 28, no. 2, p. 67. ISSN 0165-2826. The literature proposes also other position in that the agency permanent establishment is not an extension of the definition of permanent establishment, but rather is tantamount to the general permanent establishment. According to this view, these constructs are used alternatively; see e.g. WILLIAMS, R. L. Fundamentals of Permanent Establishments. $2^{\text {nd }}$ ed. Alphen aan den Rijn: Wolters Kluwer, 2014, p. 127. ISBN 978-90-411-4948-0. 
in the Article 5(4) of the OECD Model Convention, i.e. those which when carried out by the establishment in the form of a general permanent establishment would not lead to its taxation. In the current version of the OECD Model Convention of December 2017, the definition of a dependent agent has changed as a result of the OECD's work in the Base Erosion and Profit Shifting project (hereinafter referred to as the "BEPS project").

The purpose of this paper is to list the positive conditions leading to the setting up of a permanent establishment in the form of a dependent agent. First, the scope of the entities that may be considered a dependent agent should be defined. Another important issue is the manner of authorisation of a dependent agent to perform the relevant activities that lead to the creation of the permanent establishment. It is, therefore, a question of determining whether and on what basis a person has the authority to conclude contracts on behalf of the enterprise. This is important given that, under the United Nations Model Convention, an establishment will also be set up if the agent does not hold such an authority. ${ }^{3}$ In this case, a sufficient condition for setting up a permanent establishment is maintaining in the source state the storage of goods or merchandise which it regularly delivers on behalf of the enterprise. On the other hand, none of the model conventions defines the authority itself. Given the general nature of the regulation in the OECD Model Convention, this issue also needs to be confronted with the national legal systems. Having analysed the modification of the Article 5(5) of the OECD Model Convention, it can be stated that, despite its more precise content, it is still not fully adapted to the pace of development of the international economy. There is no regulation to ensure the taxation of the online business activities.

In order to fully characterise this form of a permanent establishment, it is also necessary to precisely indicate the characteristics of the agent's dependence on the enterprise. It will form a condition for setting up the establishment if any is set up. However, the determination of the charac-

\footnotetext{
3 The solutions adopted in the United Nations Model Convention related to maintaining storage of goods or merchandise is an exception to the rule. Therefore, it does not mean that under this Convention the authority to make contracts is never required. See Notes 25 - 26 of the Commentary on the Article 5 of the United Nations Model Double Taxation Convention between Developed and Developing Countries [online]. $1^{\text {st }}$ ed. New York: United Nations, Department of Economic and Social Affairs, 2011, pp. 121-122 [cit. 2020-12-11]. ISBN 978-92-1-159102-6. Available at: https://www.un.org/esa/ffd/wp-content/uploads/2014/09/UN_Model_2011_Update.pdf.
} 
teristics of the agent's dependence requires a reference to the Article 5(6) of the OECD Model Convention. In the 2014 version of the OECD Model Convention, the norm contained in the aforementioned provision excludes from the subjective scope persons whose activity constitutes the creation of a permanent establishment: a broker, a general commission agent or any other independent representative, provided that these persons are acting in the ordinary course of their activities. The provision of the Article 5(6) of the OECD Model Convention thus constitutes the boundary between the agent's dependence and independence. This paper presents the distinguishing features of the agent's dependence on the enterprise, but leaves aside the issue of negative conditions the fulfilment of which allows avoiding the creation of a permanent establishment.

\section{Subjectivity of the establishment as a dependent agent}

As mentioned above, the condition for creating an establishment in the form of a dependent agent is the activity of a person for the benefit of the enterprise. For the purposes of interpreting the subjective scope, it is reasonable to refer to the definition adopted in the Article 3(a) of the OECD Model Convention. According to it, the term "person" includes an individual, a company and any other body of persons, while the term "company" should be understood as any body corporate or any entity that is treated as a body corporate for the tax purposes. ${ }^{4}$ Thus, the OECD Model Convention adopts a broad concept of entities that can be qualified as a dependent agent.

For a natural person, the fact of employment with the enterprise, the country of residence, stay or seat, and the fact of this person maintaining a permanent place of business are irrelevant. ${ }^{5}$ It is also irrelevant whether the person is subject to limited or unlimited tax liability in the state where the contract is performed. On the other hand, the term "company" covers all bodies of persons established under the private law, public law, or even international law. Undoubtedly, these criteria will be met by companies with legal personality. On the other hand, companies without legal personality, under the national regulations of parties to the double taxation avoidance agreements, often considered to be tax transparent

4 See Article 3(b) of the OECD Model Convention of 2014 and the OECD Model Convention of 2017.

5 See E. Reimer in REIMER, E., St. SCHMID and M. ORELL, eds. Permanent Establishments: A Domestic Taxation, Bilateral Tax Treaty and OECD Perspective. $5^{\text {th }}$ ed. Alphen aan den Rijn: Wolters Kluwer, 2016, p. 102. ISBN 978-90-411-6727-9. 
entities, should be classified as the third category of entities, i.e. other bodies of persons. ${ }^{6}$ Public administration bodies may also be considered dependent agents, provided that they meet the other conditions specified in the Article 5(5) of the OECD Model Convention, as well as a number of other entities. ${ }^{7}$ This is so because the purpose of this regulation is to cover the largest possible number of entities that can be dealt with under the internal legal systems of parties to agreements on the avoidance of double taxation. ${ }^{8}$

However, the agent should be a legal entity separate from the enterprise. ${ }^{9}$ If the entrepreneur acts in his or her own name, it is not possible to establish a relationship of dependence and, as a result, the permanent establishment will not be constituted. ${ }^{10}$ This should be referred to the situation of members of the management board and shareholders with the right to represent the company. According to this position, their activities are not a condition for setting up an establishment in the form of a dependent agent. The effects of board member's actions will be attributed to the legal person he or she represents. ${ }^{11}$ Similar case is for a partner of a partnership who is a statutory representative of the partnership. ${ }^{12}$ Therefore, in this case, only an employee of the enterprise, forming part of its organisational structures under a contract, will meet the condition of separateness.

6 See LIPNIEWICZ, R. Podatkowy zakład zagraniczny: Koncepcja i funkcjonowanie. 1. wyd. Warszawa: Wolters Kluwer, 2017, p. 122. ISBN 978-83-8092-832-9.

7 See E. Reimer in REIMER, E., St. SCHMID and M. ORELL, eds. Permanent Establishments: A Domestic Taxation, Bilateral Tax Treaty and OECD Perspective. $5^{\text {th }}$ ed. Alphen aan den Rijn: Wolters Kluwer, 2016, p. 103. ISBN 978-90-411-6727-9.

8 See BANACH, J. Polskie umowy o unikaniu podwójnego opodatkowania: Komentarz. 2. wyd. Warszawa: C. H. Beck, 2002, p. 100. ISBN 83-7247-904-6.

9 See FEUERSTEIN, D. The Agency Permanent Establishment. In: F. BRUGGER and P. PLANSKY, eds. Permanent Establishments in International and EU Tax Law. $1^{\text {st }}$ ed. Wien: Linde, 2011, p. 110. Series on International Tax Law, no. 68. ISBN 978-3-7073-2003-9.

10 There is also a different view presented in the literature that both employees, the boards of companies and the partners of partnerships equipped with signatory powers may be classified as dependent agents. See E. Reimer in REIMER, E. and A. RUST, eds. Klaus Vogel on Double Taxation Conventions: Volume I. $4^{\text {th }}$ ed. Alphen aan den Rijn: Wolters Kluwer, 2015, p. 386. ISBN 978-90-411-2298-8.

${ }^{11}$ See Decision of the Supreme Court of the Republic of Poland Ref. No. IV CSK 413/09 [201003-11]. LEX no. 677902.

${ }^{12}$ More on the subject of rights of a shareholder/partner in terms of signatory powers see in KIDYBA, A. red. Kodeks spółek handlowych: Tom I: Komentarz do art. 1 - 150. 1. wyd. Warszawa: Wolters Kluwer, 2017, p. 199. ISBN 978-83-8107-239-7. 
Taking into account the relationship between the enterprise and the dependent agent whose business will constitute a permanent establishment, three types of dependent agents can be distinguished. Firstly, a person who can be referred to as an internal agent, who, as a rule, is a person employed by the enterprise. ${ }^{13}$ This could, therefore, include an enterprise employee delegated to conclude contracts with clients outside the company's tax residence. The second category includes agents located outside of the enterprise structure and who are employed by another enterprise in the territory of the source state, not linked to the former in the sense of remaining under common control. ${ }^{14}$ These conditions shall be met by an enterprise hired as a distributor in the source state. Finally, the third type of agent is a person who is not part of the company structure, but who is linked to it, e.g. as a sister company, and who has the right to represent the enterprise outside its country of residence as well as the habitual exercise of the right to enter into contracts binding on that company. ${ }^{15}$ This distinction is relevant in the context of the Article 7 of the OECD Model Convention, i.e. the method of attributing profits to an establishment acting in the form of a dependent agent, and affects the amount of profit attributed to it. The definition of person and company has remained unchanged in the OECD Model Convention in its 2017 version.

\section{Characteristics of the dependent agent}

The attributes of the agent's dependence on the company are set out in the provision of the Article 5(5) of the OECD Model Convention. A functional condition the fulfilment of which will result in setting up an establishment in the form of a dependent agent is that the person has an authority to conclude contracts on behalf of the enterprise. Moreover, this

${ }^{13}$ See BAKER, Ph. Dependent Agent Permanent Establishments: Recent OECD Trends. In: M. LANG, P. PISTONE, J. SCHUCH, C. STARINGER and A. STORCK, eds. Dependent Agents as Permanent Establishments. $1^{\text {st }}$ ed. Wien: Linde, 2014, p. 25. Series on International Tax Law, no. 85. ISBN 978-3-7073-2460-0.

${ }^{14}$ See BAKER, Ph. Dependent Agent Permanent Establishments: Recent OECD Trends. In: M. LANG, P. PISTONE, J. SCHUCH, C. STARINGER and A. STORCK, eds. Dependent Agents as Permanent Establishments. $1^{\text {st }}$ ed. Wien: Linde, 2014, p. 25. Series on International Tax Law, no. 85. ISBN 978-3-7073-2460-0.

${ }^{15}$ See BAKER, Ph. Dependent Agent Permanent Establishments: Recent OECD Trends. In: M. LANG, P. PISTONE, J. SCHUCH, C. STARINGER and A. STORCK, eds. Dependent Agents as Permanent Establishments. $1^{\text {st }}$ ed. Wien: Linde, 2014, p. 26. Series on International Tax Law, no. 85. ISBN 978-3-7073-2460-0. 
authority must be exercised continuously and not just incidentally. ${ }^{16}$ The authority to conclude contracts may be general or specific, i.e. limited to a certain type of contracts or geographical area. However, it is crucial to determine whether the contracts concluded by the intermediary are binding on the enterprise. ${ }^{17}$

Neither the wording of the Article 5(5) of the OECD Model Convention nor its Commentary is specific about how to understand the phrase "authority to conclude contracts". It may be, first, an internal relationship, also known as a basic one, between the intermediary and the enterprise, from which the obligation to represent a foreign enterprise results. In another sense, an authority to make contracts is an external relationship between an intermediary and a third party who in good faith concludes a contract with the former. ${ }^{18}$ This issue has not been unequivocally resolved under the international tax law. From the client's point of view, however, it is irrelevant that the intermediary has an authority to conclude contracts on behalf of the enterprise. The lack of involvement of the enterprise in the process of contract-making may mean that the process is delegated to its agent. It should then be presumed that the acts carried out by the agent are based on an appropriate authorisation and, therefore, have legal effects on the enterprise. ${ }^{19}$ However, irrespective of the type of relationship, whether internal or external, the representative may not be regarded as acting on behalf of the principal if the acts he or she has taken would have clearly infringed the authorisation conferred on him or her. ${ }^{20}$ It would be appropriate to introduce the requirement of

\footnotetext{
${ }^{16} \mathrm{Cf}$. Article 5(5) of the OECD Model Convention of 2014.

${ }^{17}$ See FEUERSTEIN, D. The Agency Permanent Establishment. In: F. BRUGGER and P. PLANSKY, eds. Permanent Establishments in International and EU Tax Law. $1^{\text {st }}$ ed. Wien: Linde, 2011, p. 111. Series on International Tax Law, no. 68. ISBN 978-3-7073-2003-9.

${ }^{18}$ See FEUERSTEIN, D. The Agency Permanent Establishment. In: F. BRUGGER and P. PLANSKY, eds. Permanent Establishments in International and EU Tax Law. $1^{\text {st }}$ ed. Wien: Linde, 2011, p. 111. Series on International Tax Law, no. 68. ISBN 978-3-7073-2003-9.

${ }^{19}$ Cf. paragraph 32.1 of the Commentary on the Article 5 of the OECD Model Convention of 2014. See Model Tax Convention on Income and on Capital: Condensed Version [2014] [online]. $1^{\text {st }}$ ed. Paris: Organisation for Economic Co-operation and Development, 2014, pp. 107-108 [cit. 2020-12-11]. ISBN 978-92-64-21937-3. Available at: https://doi.org/10. 1787/mtc_cond-2014-en; and O. Łunarski in BRZEZIŃSKI, B. red. Model konwencji OECD: Komentarz. 1. wyd. Warszawa: „Oficyna Prawa Polskiego“ - Wydawnictwo Wiedza i Praktyka, 2010, p. 356. ISBN 978-83-7677-161-8.

${ }^{20}$ See SCHAFFNER, J. How Fixed Is Permanent Establishment?. $1^{\text {st }}$ ed. Alphen aan den Rijn: Wolters Kluwer, 2013, p. 230. Series on International Taxation, no. 42. ISBN 978-90-4114662-5.
} 
confirmation by the principal of a contract concluded by the representative on behalf of the enterprise.

There is no one form in which a dependent agent may be authorised to enter into contracts on behalf of an enterprise. ${ }^{21}$ Within the civil-law culture, it will, in principle, be a contractual relationship between the principal and the representative. The key issue, however, is the circumstances of granting the authorisation which effectively entitles the representative to act in someone else's name. The authority may, therefore, be granted formally or implicitly, provided that the enterprise and the representative agree on the powers conferred. However, according to the Commentary on the OECD Model Convention, it is not a sufficient argument to justify the correct empowerment of the representative by the mere fact that he or she was involved in negotiations or the conclusion of a contract. ${ }^{22}$ In addition, the contracts concluded by the representative should concern the substance of the enterprise's business. ${ }^{23}$

In the literature on the subject, the issue of the form of authorisation of a dependent agent is usually completely ignored, which may result from the lack of such regulations under the OECD Model Convention and the lack of guidance in its Commentary. Therefore, according to the rule contained in the Article 3(2) of the OECD Model Convention, if the international tax law, due to its universality, does not contain relevant regulations, then the national regulations shall apply. ${ }^{24}$ In the case of agreements for avoidance of double taxation to which the Republic of Poland is a party, the legal dependency of an agent should, therefore, be analysed

${ }^{21}$ See PLEIJSIER, A. The Agency Permanent Establishment: The Current Definition - Part One. Intertax. 2001, vol. 29, no. 5, p. 170. ISSN 0165-2826.

${ }^{22}$ Cf. paragraph 33 of the Commentary on the Article 5 of the OECD Model Convention of 2014. See Model Tax Convention on Income and on Capital: Condensed Version [2014] [online]. $1^{\text {st }}$ ed. Paris: Organisation for Economic Co-operation and Development, 2014, p. 108 [cit. 2020-12-11]. ISBN 978-92-64-21937-3. Available at: https://doi.org/10.17 87/mtc_cond-2014-en.

${ }^{23}$ See LIPNIEWICZ, R. Podatkowy zakład zagraniczny: Koncepcja i funkcjonowanie. 1. wyd. Warszawa: Wolters Kluwer, 2017, p. 140. ISBN 978-83-8092-832-9.

24 The problems with the interpretation of the term "authority" could be resolved under the international private law. Parties to the double taxation agreements would each time specify the jurisdiction competent for determining the authority to conclude contracts. Article 3(2) of the OECD Model Convention does not exclude such a solution; Cf. Article 4 of the Act of February 4, 2011 - International Private Law [Consolidated Text] [2011-0204]. Journal of Laws, 2015, item 1792 [in the Polish original Ustawa z dnia 4 lutego 2011 r. - Prawo prywatne międzynarodowe [tekst skonsolidowany] [2011-02-04]. Dziennik Ustaw, 2015, poz. 1792]. 
with reference to the norms of the Polish private law. ${ }^{25}$ If the contract between the agent and the enterprise does not contain any applicable jurisdiction provisions, it means that, in fact, two systems will apply: the jurisdiction of the state of the principal if the principal's status is under examination in the state of residence and the legal system of the agent's state if his or her authorisation is being examined by the tax authorities of the source state. ${ }^{26}$

A duly authorized representative with the right to conclude contracts on behalf of the enterprise may also grant further powers of attorney. Such action, however, requires the prior consent of his or her principal. The scope of activities to be performed by the substitute is the original scope of powers granted. If an enterprise has two or more agents in the territory of the source country, but only one of them has a contractual relationship with the enterprise, it is considered that only one permanent establishment will be constituted. ${ }^{27}$

A dependent agent does not need to be territorially linked to the source state. This means that the source state does not have to be the agent's country of tax residence or citizenship. However, the agent is obliged to be present in the territory of the source state when concluding contracts on behalf of the enterprise being represented. ${ }^{28}$ Moreover, the habitual exercise of the authority by him or her should be characterized by a certain degree of frequency and permanence, which allows distinguishing it from an incidental or occasional activity. ${ }^{29}$ The assessment should be each time based on an analysis of the factual circumstances, especially the nature of the business of the enterprise. The solution to be

\footnotetext{
${ }^{25}$ See WOŹNIAK, T. Zależność prawna przedstawiciela od przedsiębiorstwa jako warunek powstania zakładu w międzynarodowym prawie podatkowym. In: J. GLINIECKA, A. DRYWA, E. JUCHNIEWICZ and T. SOWIŃSKI, red. Praktyczne i teoretyczne problemy prawa finansowego wobec wyzwań XXI wieku [The Practical and Theoretical Problems of Financial Law towards Challenges of the XXI Century]. 1. wyd. Warszawa: CeDeWu, 2017, p. 501. ISBN 978-83-7556-960-5.

${ }^{26}$ See PLEIJSIER, A. The Agency Permanent Establishment: The Current Definition - Part One. Intertax. 2001, vol. 29, no. 5, p. 171. ISSN 0165-2826.

${ }^{27}$ See PLEIJSIER, A. The Agency Permanent Establishment: The Current Definition - Part One. Intertax. 2001, vol. 29, no. 5, p. 174. ISSN 0165-2826.

${ }^{28}$ See E. Reimer in REIMER, E. and A. RUST, eds. Klaus Vogel on Double Taxation Conventions: Volume I. $4^{\text {th }}$ ed. Alphen aan den Rijn: Wolters Kluwer, 2015, p. 388. ISBN 978-90411-2298-8.

${ }^{29}$ See SCHAFFNER, J. How Fixed Is Permanent Establishment?. $1^{\text {st }}$ ed. Alphen aan den Rijn: Wolters Kluwer, 2013, p. 232. Series on International Taxation, no. 42. ISBN 978-90-4114662-5.
} 
adopted would, however, lead to the granting by the company of an authority to a considerable number of agents, so that none of them would exercise his or her authority with an appropriate frequency. Although it would entail low effectiveness for the enterprise, this factor should also be taken into account when analysing the authority for the agent in order to examine whether a permanent establishment has been set up. ${ }^{30}$

The tangible effect of the Organisation for Economic Co-operation and Development's work under the BEPS Action 7 is the changes made to the definition of permanent establishment, which also concern the content of the definition of a dependent agent. Currently, pursuant to the Article 5(5) of the 2017 OECD Model Convention, the dependent agent is a person who acts on behalf of the enterprise in the source state. This should be understood that the person is involved in the habitual conclusion of contracts or habitually plays a key role in the conclusion by the enterprise of routine contracts which are not subject to further modification.

The prior requirement of authorising an agent to enter into contracts on behalf of an enterprise is supplemented by a further criterion which gives the definition of a dependent agent a more specific shape. In qualitative terms, the replacement of the expression "habitually" by the expression "routinely" does not essentially imply the need for a different interpretation. Both forms require continuous, repeated activities, so this does not affect the duration and frequency of the activities of a dependent agent. However, this is relevant in subjective terms, since the expression "habitually" was referring to a dependent agent, whereas the expression "routinely" must be interpreted in the context of the enterprise represented by an agent. If the enterprise is actively involved in the negotiations or where these negotiations lead to a modification of the contract, the activities of the dependent agent cannot be attributed the routine character. He or she does not play a key role in the conclusion of contracts either.

Therefore, the new wording of the Article 5(5) of the OECD Model Convention covers also the criteria relating to the nature of contracts concluded between an enterprise and a third party in the source state. In accordance with the Article 5(5)(a) of the OECD Model Convention, these

${ }^{30}$ See SCHAFFNER, J. How Fixed Is Permanent Establishment?. $1^{\text {st }}$ ed. Alphen aan den Rijn: Wolters Kluwer, 2013, p. 233. Series on International Taxation, no. 42. ISBN 978-90-4114662-5. 
agreements shall be concluded in the name of the enterprise. This also applies to a situation where the name of the enterprise is not expressly disclosed in the contract. ${ }^{31}$ As a rule, the concept resembles that of the previous version of the OECD Model Convention. In reality, however, it goes far beyond the interpretation adopted so far, since it concerns all contracts concluded by or on behalf of an enterprise. Importantly, the conclusion of a contract by a dependent agent personally is not a formal requirement as it was before.

The next two criteria regarding contracts are a novelty under the OECD Model Convention. They apply only where an enterprise runs a business involving delivery of goods or services. Therefore, concluding a contrario, enterprises which receive goods or services have been excluded from the subjective scope. In their case, the establishment is set up only if the contract meets the conditions of the Article 5(5)(a) of the OECD Model Convention. Where the enterprise is a supplier of goods or services, it is irrelevant whether the dependent agent has concluded a contract on behalf of the enterprise or was only involved in negotiating its terms.

However, for the criteria listed in the Article 5(5)(b) and (c) of the OECD Model Convention, the economic grounds for linking an agreement negotiated, concluded or merely arranged by a dependent agent should be demonstrated. Importantly, the Commentary on the OECD Model Convention clarifies that a person acts on behalf of an enterprise when particularly engaging the enterprise in the business activities in the source state. It is indicated that such persons will be a contractor, a partner or a company board member as well as an employee of the enterprise. However, the person does not act on behalf of the enterprise if the actions undertaken by him or her do not directly or indirectly affect the enterprise. ${ }^{32}$ This is about contracts concluded for the purpose of transferring the ownership of the assets of the enterprise, granting the right to

${ }^{31}$ Cf. paragraph 93 of the Commentary on the Article 5 of the OECD Model Convention of 2017. See Model Tax Convention on Income and on Capital: Condensed Version [2017] [online]. $1^{\text {st }}$ ed. Paris: Organisation for Economic Co-operation and Development, 2017, p. 144 [cit. 2020-12-11]. ISBN 978-92-64-28795-2. Available at: https://doi.org/10.17 87/mtc_cond-2017-en.

${ }^{32}$ Cf. paragraph 86 of the Commentary on the Article 5 of the OECD Model Convention of 2017. See Model Tax Convention on Income and on Capital: Condensed Version [2017] [online]. $1^{\text {st }}$ ed. Paris: Organisation for Economic Co-operation and Development, 2017, p. 142 [cit. 2020-12-11]. ISBN 978-92-64-28795-2. Available at: https://doi.org/10.17 87/mtc_cond-2017-en. 
use the assets of the enterprise or providing services by that enterprise. ${ }^{33}$ For the purposes of the Article 5(5)(b) of the OECD Model Convention, it is irrelevant whether the agent disposes of property which already exists or which is to be produced by the enterprise immediately prior to delivery to the client. ${ }^{34}$ The term "property" should be understood narrowly in this case. It, therefore, refers to a set of tangible and intangible assets, in particular the ownership of movable and immovable property, but also copyright or receivables. Only claims will be excluded.

To prevent the artificial splitting of contracts, the Commentary on the OECD Model Convention contains detailed guidelines defining the situations when the activity of a person will lead to the setting up of an establishment. ${ }^{35}$ As it has already been mentioned, a contract may be concluded by an agent also without negotiating the terms. This applies to the conclusion of a contract as a result of the acceptance of a third party's offer by the agent on behalf of the enterprise. However, where the terms and conditions of a contract are negotiated, it is concluded by the person negotiating the terms and details of the contract in a way which is binding for the enterprise. It is irrelevant that it is signed on behalf of the enterprise by another person or outside the territory of the state where its terms are to be performed.

The habitual playing of the crucial role in concluding contracts routinely concluded by the enterprise, without additional modifications, will, therefore, relate to the person who solicits orders and then passes them on to the enterprise. ${ }^{36}$ The orders will then be fulfilled directly from the enterprise's warehouse, where transactions will be routinely approved. If

${ }^{33}$ See Article 5 of the OECD Model Convention of 2017.

${ }^{34}$ Cf. paragraph 95 of the Commentary on the Article 5 of the OECD Model Convention of 2017. See Model Tax Convention on Income and on Capital: Condensed Version [2017] [online]. $1^{\text {st }}$ ed. Paris: Organisation for Economic Co-operation and Development, 2017, p. 145 [cit. 2020-12-11]. ISBN 978-92-64-28795-2. Available at: https://doi.org/10.17 87/mtc_cond-2017-en.

${ }^{35}$ Cf. paragraph 87 of the Commentary on the Article 5 of the OECD Model Convention of 2017. See Model Tax Convention on Income and on Capital: Condensed Version [2017] [online]. $1^{\text {st }}$ ed. Paris: Organisation for Economic Co-operation and Development, 2017, p. 142 [cit. 2020-12-11]. ISBN 978-92-64-28795-2. Available at: https://doi.org/10.17 $87 /$ mtc_cond-2017-en.

${ }^{36}$ Cf. paragraph 89 of the Commentary on the Article 5 of the OECD Model Convention of 2017. See Model Tax Convention on Income and on Capital: Condensed Version [2017] [online]. $1^{\text {st }}$ ed. Paris: Organisation for Economic Co-operation and Development, 2017, p. 143 [cit. 2020-12-11]. ISBN 978-92-64-28795-2. Available at: https://doi.org/10.17 87/mtc_cond-2017-en. 
the transaction eventually does not take place, so that the agent's activity consists only of promoting and marketing the goods, then the Article 5(5) of the OECD Model Convention 2017 will not apply.

\section{Permanent establishment in the form of a dependent agent in the context of electronic transactions}

The permanent establishment in the form of a dependent agent may also be considered in the context of its specific forms: firstly, a subsidiary; ${ }^{37}$ secondly, an insurance company; thirdly, a business running as e-commerce. The first two operate under certain double taxation agreements modelled on the OECD Model Convention, but with some modifications. However, a dependent agent as a form of permanent establishment in the electronic commerce is postulated in the literature. This is so, because no construction has been devised yet to enable the taxation of the ecommerce activities, which, after all, significantly engages a foreign enterprise in economic relations outside the state of residence.

An e-commerce permanent establishment has not been literally mentioned in the Article 5 of the OECD Model Convention. However, ecommerce is the subject of guidance in the Commentary on the OECD Model Convention. The key issue here is whether the information technology device used by a foreign enterprise for commercial purposes in a contracting state can be a permanent establishment. Importantly, according to the Organisation for Economic Co-operation and Development's position, an e-commerce transaction is the sale or purchase of goods or services, conducted over computer networks by methods specifically designed for the purpose of receiving or placing of orders, but the ultimate payments do not have to be conducted online. ${ }^{38}$

It is also necessary to distinguish between the concepts of the devices by which transactions are carried out and the software used to enter into those transactions. ${ }^{39}$ The device referred to in the Commentary on

\footnotetext{
${ }^{37}$ In the Polish national law, the relationship of dependence and domination between companies should be considered under the Article 4 § 1(4) of the Code of Commercial Companies and Partnerships [2000-09-15].

${ }^{38}$ See OECD Guide to Measuring the Information Society 2011 [online]. $1^{\text {st }}$ ed. Paris: Organisation for Economic Co-operation and Development, 2011, p. 72 [cit. 2020-12-11]. ISBN 978-92-64-11354-1. Available at: https://doi.org/10.1787/9789264113541-en.

${ }^{39}$ Cf. paragraph 122 of the Commentary on the Article 5 of the OECD Model Convention of 2017. See Model Tax Convention on Income and on Capital: Condensed Version [2017] [online]. $1^{\text {st }}$ ed. Paris: Organisation for Economic Co-operation and Development, 2017,
} 
the OECD Model Convention is a server that can be considered a general permanent establishment of an enterprise, provided that it remains indoors for a certain period of time, as it meets an essential condition for the setting up of a permanent establishment in that form, namely the durability of the establishment. However, this will not result in the permanent establishment set up if the server is owned by an internet service provider. On the other hand, concerning the software used to enter into transactions, the Commentary on the OECD Model Convention only mentions a website. Due to its intangible nature and the absence of separation in the form of occupied premises, it cannot constitute a permanent establishment in the form of a general permanent establishment. ${ }^{40}$

In the context of the permanent establishment in the form of a dependent agent, the Commentary on the OECD Model Convention determines whether Internet service providers which make their servers available to foreign entrepreneurs may constitute a permanent establishment within the meaning of the Article 5(5) of the OECD Model Convention. According to the position proposed by the Organisation for Economic Co-operation and Development, it is not possible here to constitute a permanent establishment in the form of a dependent agent. ${ }^{41}$ Internet service providers do not normally act as representatives of an enterprise which owns websites. This is so, because they do not have the appropriate authority to conclude contracts on their behalf which are binding on the enterprise. The construct proposed in the OECD Model Convention does not include such a solution, even after its revision in year 2017. The positions different from that adopted appear in the literature on the subject.

However, the issue of recognising a server as a dependent agent of an enterprise needs to be considered. It could meet most of the conditions

pp. 151-152 [cit. 2020-12-11]. ISBN 978-92-64-28795-2. Available at: https://doi.org/10. $1787 /$ mtc_cond-2017-en.

${ }^{40}$ Cf. paragraph 151 of the Commentary on the Article 5 of the OECD Model Convention of 2017. See Model Tax Convention on Income and on Capital: Condensed Version [2017] [online]. $1^{\text {st }}$ ed. Paris: Organisation for Economic Co-operation and Development, 2017, p. 159 [cit. 2020-12-11]. ISBN 978-92-64-28795-2. Available at: https://doi.org/10.17 87/mtc_cond-2017-en.

${ }^{41}$ Cf. paragraph 131 of the Commentary on the Article 5 of the OECD Model Convention of 2017. See Model Tax Convention on Income and on Capital: Condensed Version [2017] [online]. $1^{\text {st }}$ ed. Paris: Organisation for Economic Co-operation and Development, 2017, p. 154 [cit. 2020-12-11]. ISBN 978-92-64-28795-2. Available at: https://doi.org/10.17 87/mtc_cond-2017-en. 
for the setting up of a permanent establishment in the form discussed herein. Contracts that bind the enterprise would be concluded using a server if this were to be done at the appropriate frequency, and the requirement of routine action would also be met. The only drawback of such an approach will be that it will not be possible to recognise the fulfilment of the subjective criterion, even though the definition of a "person" in the Article 3 of the OECD Model Convention is broad. A similar position applies to the second medium used in e-commerce, i.e. websites. It will also not meet the conditions for recognition as a "person". However, the literature presents positions aimed at recognising the website as a dependent agent. ${ }^{42}$ As in the case of the server, it is used for concluding contracts on behalf of the enterprise in a binding manner. Such an interpretation seems not to be valid, also after recent changes in the definition of a dependent agent.

\section{Final remarks}

The method of direct investment in foreign markets most frequently used by enterprises is the use of the structure of a foreign establishment. It is an integral part of the enterprise's business in the source country. Given the intensity and complexity of international economic relations, the taxation rules designed years ago have been put to a test. Their flaws triggered a tendency towards tax avoidance by entities operating transnationally. This, in turn, required a revision of the provisions of the OECD Model Convention which is supposed to ensure the taxation of profits in the place where they are earned, thus in the place of business. The BEPS project, led by the Organisation for Economic Co-operation and Development and the G20 countries, has involved representatives of all member countries of the Organisation for Economic Co-operation and Development, both businesspeople and members of the academia. Therefore, it can be stated that the solutions adopted are the result of international consensus. The BEPS project aims to solve specific problems, not to radically change the taxation system. However, the success of these actions depends on whether the states parties to the double taxation agreements based on the OECD Model Convention decide to introduce the proposed changes.

\footnotetext{
${ }^{42}$ See BASU, S. Global Perspectives on E-commerce Taxation Law [online]. $1^{\text {st }}$ ed. London: Routledge, 2007, p. 118 [cit. 2020-12-11]. ISBN 978-1-315-58497-3. Available at: https:// doi.org/10.4324/9781315584973.
} 
The adoption of a new definition of a permanent establishment into the law as it stands now, provided that it is implemented by the states parties to the double taxation agreements modelled on the OECD Model Convention, has a significant impact on the international tax law. The solutions proposed by the Organisation for Economic Co-operation and Development provide new standards for setting up a permanent establishment and have a direct impact on the method of attributing to it profits achieved by the enterprise in the source state. Apart from the method of attributing profits to the permanent establishment, the Organisation for Economic Co-operation and Development's work under the Action 7 addressed three main areas: first, avoiding the permanent establishment status through commissionaire; second, avoiding the permanent establishment status by performing certain activities and splitting activities between related entities; third, other strategies to avoid the permanent establishment status, such as splitting contracts or methods of selling insurance.

Another challenge for entities applying the international tax law is the growth of e-commerce. Without further introducing relevant changes in the definition of permanent establishment set out in the Article 5 of the OECD Model Convention and, as a consequence, in the provisions of individual tax treaties, the Internet enterprises will still effectively evade taxation. Therefore, it is difficult to agree with the Organisation for Economic Co-operation and Development's terminology that the avoidance of the permanent establishment status is artificial. The taxpayers only take advantage of the flaws of the definition of permanent establishment or use the exemptions under the Article 5(4) of the OECD Model Convention, which shows that the content of the OECD Model Convention adopted many years ago does not match the pace of changes in the contemporary global economy. Despite the modification of the definition of permanent establishment in the 2017 OECD Model Convention, it should be stated that the Organisation for Economic Co-operation and Development's actions are characterised by the lack of radicalism.

\section{References}

Act of February 4, 2011 - International Private Law [Consolidated Text] [2011-02-04]. Journal of Laws, 2015, item 1792 [in the Polish original Ustawa z dnia 4 lutego 2011 r. - Prawo prywatne międzynarodowe [tekst skonsolidowany] [2011-02-04]. Dziennik Ustaw, 2015, poz. 1792]. 
BAKER, Ph. Dependent Agent Permanent Establishments: Recent OECD Trends. In: M. LANG, P. PISTONE, J. SCHUCH, C. STARINGER and A. STORCK, eds. Dependent Agents as Permanent Establishments. $1^{\text {st }}$ ed. Wien: Linde, 2014, pp. 23-32. Series on International Tax Law, no. 85. ISBN 978-3-7073-2460-0.

BANACH, J. Polskie umowy o unikaniu podwójnego opodatkowania: Komentarz. 2. wyd. Warszawa: C. H. Beck, 2002. 448 p. ISBN 83-7247904-6.

BASU, S. Global Perspectives on E-commerce Taxation Law [online]. $1^{\text {st }}$ ed. London: Routledge, 2007. 333 p. [cit. 2020-12-11]. ISBN 978-1-31558497-3. Available at: https://doi.org/10.4324/9781315584973.

BRZEZIŃSKI, B. red. Model konwencji OECD: Komentarz. 1. wyd. Warszawa: „Oficyna Prawa Polskiego“ - Wydawnictwo Wiedza i Praktyka, 2010. 1393 p. ISBN 978-83-7677-161-8.

Code of Commercial Companies and Partnerships [2000-09-15].

Decision of the Supreme Court of the Republic of Poland Ref. No. IV CSK 413/09 [2010-03-11]. LEX no. 677902.

FEUERSTEIN, D. The Agency Permanent Establishment. In: F. BRUGGER and P. PLANSKY, eds. Permanent Establishments in International and EU Tax Law. $1^{\text {st }}$ ed. Wien: Linde, 2011, pp. 105-124. Series on International Tax Law, no. 68. ISBN 978-3-7073-2003-9.

JAMROŻY, M. Planowanie podatkowe działalności prowadzonej poprzez zagraniczny zakład. Studia Ekonomiczne. 2014, nr 198, pp. 255-266. ISSN 2083-8611.

KIDYBA, A. red. Kodeks spółek handlowych: Tom I: Komentarz do art. 1 150. 1. wyd. Warszawa: Wolters Kluwer, 2017. 877 p. ISBN 978-838107-239-7.

LIPNIEWICZ, R. Podatkowy zakład zagraniczny: Koncepcja i funkcjonowanie. 1. wyd. Warszawa: Wolters Kluwer, 2017. 290 p. ISBN 978-838092-832-9.

Model Tax Convention on Income and on Capital: Condensed Version [2014] [online]. $1^{\text {st }}$ ed. Paris: Organisation for Economic Co-operation and Development, 2014. 492 p. [cit. 2020-12-11]. ISBN 978-9264-21937-3. Available at: https://doi.org/10.1787/mtc_cond-2014en. 
Model Tax Convention on Income and on Capital: Condensed Version [2017] [online]. $1^{\text {st }}$ ed. Paris: Organisation for Economic Co-operation and Development, 2017. 654 p. [cit. 2020-12-11]. ISBN 978-9264-28795-2. Available at: https://doi.org/10.1787/mtc_cond-2017en.

OECD Guide to Measuring the Information Society 2011 [online]. $1^{\text {st }}$ ed. Paris: Organisation for Economic Co-operation and Development, 2011. 204 p. [cit. 2020-12-11]. ISBN 978-92-64-11354-1. Available at: https://doi.org/10.1787/9789264113541-en.

OECD Model Convention of 2014.

OECD Model Convention of 2017.

PERSICO, G. Agency Permanent Establishment under Article 5 of the OECD Model Convention. Intertax. 2000, vol. 28, no. 2, pp. 66-81. ISSN 0165-2826.

PLEIJSIER, A. The Agency Permanent Establishment: The Current Definition - Part One. Intertax. 2001, vol. 29, no. 5, pp. 167-183. ISSN 01652826.

REIMER, E. and A. RUST, eds. Klaus Vogel on Double Taxation Conventions: Volume I. $4^{\text {th }}$ ed. Alphen aan den Rijn: Wolters Kluwer, 2015. 1087 p. ISBN 978-90-411-2298-8.

REIMER, E., St. SCHMID and M. ORELL, eds. Permanent Establishments: A Domestic Taxation, Bilateral Tax Treaty and OECD Perspective. $5^{\text {th }}$ ed. Alphen aan den Rijn: Wolters Kluwer, 2016. 893 p. ISBN 97890-411-6727-9.

SCHAFFNER, J. How Fixed Is Permanent Establishment?. $1^{\text {st }}$ ed. Alphen aan den Rijn: Wolters Kluwer, 2013. 329 p. Series on International Taxation, no. 42. ISBN 978-90-411-4662-5.

United Nations Model Double Taxation Convention between Developed and Developing Countries [online]. $1^{\text {st }}$ ed. New York: United Nations, Department of Economic and Social Affairs, 2011. 483 p. [cit. 2020-1211]. ISBN 978-92-1-159102-6. Available at: https://www.un.org/ esa/ffd/wp-content/uploads/2014/09/UN_Model_2011_Update.pdf.

WILliAMS, R. L. Fundamentals of Permanent Establishments. $2^{\text {nd }}$ ed. Alphen aan den Rijn: Wolters Kluwer, 2014. 300 p. ISBN 978-90-4114948-0. 
WOŹNIAK, T. Zależność prawna przedstawiciela od przedsiębiorstwa jako warunek powstania zakładu w międzynarodowym prawie podatkowym. In: J. GLINIECKA, A. DRYWA, E. JUCHNIEWICZ and T. SOWIŃSKI, red. Praktyczne i teoretyczne problemy prawa finansowego wobec wyzwań XXI wieku [The Practical and Theoretical Problems of Financial Law towards Challenges of the XXI Century]. 1. wyd. Warszawa: CeDeWu, 2017, pp. 501-510. ISBN 978-83-7556-960-5.

M.L. Agata Lipińska

Faculty of Law and Administration Maria Curie-Skłodowska University Plac Marii Curie-Skłodowskiej 5 20-031 Lublin Poland agata.lipinska@umcs.pl (iD) https://orcid.org/0000-0002-7739-9537 